\title{
Structural and stereospecific requirements for the nucleoside-triggered germination of Bacillus cereus spores
}

\author{
Sonia Senesi, ${ }^{1 *}$ Giovanni Cercignani, ${ }^{2}$ Giulia Freer, ${ }^{1}$ Giovanna Batoni, ${ }^{1}$ Simona Barnini ${ }^{1}$ \\ and Fusao OTA ${ }^{1} \dagger$
}

${ }^{1}$ Department of Biomedicine, Medical Microbiology Section, Via S. Zeno 39, and ${ }^{2}$ Department of Physiology and Biochemistry, Via S. Maria 55, University of Pisa, 56100 Pisa, Italy

(Received 16 July 1990; revised 24 September 1990; accepted 25 October 1990)

\begin{abstract}
A selection of adenosine analogues was tested for their ability to trigger germination of Bacillus cereus NCIB 8122 spores. The germination-inducing activity was governed by the structural properties of the sugar rather than the base moieties of the nucleosides. Among the sugar-modified analogues, only those containing a 2'-deoxy-D-ribose moiety promoted spore germination. Requirements for a specific molecular structure of the base were not clearly identified, although the highest activity was observed when substituents were inserted at position 6 of the purine ring. All the base-modified analogues, even those such as coformycin and $2^{\prime}$-deoxycoformycin with an expanded base ring, retained the germination-inducing activity of adenosine. However, of the two $2^{\prime}$-deoxycoformycin diastereoisomers characterized by an asymmetric carbon atom at position 8 of the homopurine ring, only the 8Sisomer induced germination, thus indicating that stereospecific configuration of the inducer, at least in the case of $2^{\prime}$-deoxycoformycin, appears to be essential for the initiation of spore germination. The differences in the germination-inducing activity of the various analogues tested were not affected significantly by spore activation at different temperatures, although the higher the activation temperature, the lower was the concentration of each analogue required for maximum germination.
\end{abstract}

\section{Introduction}

The molecular mechanism of bacterial spore germination is still the subject of intense investigation. Much is known of the conditions under which spores germinate and detailed information has been accumulated on the biochemical changes that accompany the sequential loss of spore properties during germination (Keynan, 1978; Setlow, 1983). On the other hand, very little is known of the nature of the reaction responsible for the initiation of germination, although there is increasing evidence to suggest that the 'trigger reaction' might be an allosteric change involving the binding of an inner-membrane receptor to exogenous germinants, rather than a metabolic energy-requiring event (Keynan \& Sandler, 1983; Foster \& Johnstone, 1990).

Purine nucleosides induce germination of spores of several bacterial species (Hills, $1949 a$; Lawrence, 1955b; Powell \& Hunter, 1955, 1956), but the mechanism of

+ Permanent address: Department of Food Microbiology, School of Medicine, University of Tokushima, Tokushima 770, Japan.

Abbreviation: DPA, dipicolinic acid. their action is far from fully understood. For Bacillus cereus spores only certain purine compounds induce germination (Hills, 1949a; Powell \& Hunter, 1956; Warren \& Gould, 1968) and their effectiveness is greatly influenced by prolonged heat treatment (Powell \& Hunter, 1955, 1956). Inosine, adenosine and guanosine induce spore germination to a variable extent, but xanthosine and purine and pyrimidine nucleotides are inactive, as are the constituents of purine nucleosides, free bases and sugars tested individually and in combination (Hills, $1949 a$; Lawrence, 1955b; Warren \& Gould, 1968).

Intact spores of $B$. cereus contain enzymes which catalyse the breakdown of purine nucleosides as soon as germination is induced (Lawrence, 1955a, $b$; Powell \& Hunter, 1956; Senesi et al., 1977; Weinberger et al., 1980), which suggested that only metabolizable nucleosides would induce germination even though their cleavage did not appear essential to trigger germination (Lawrence, 1955a; Powell \& Hunter, 1956; Weinberger et al., 1980). More recently, non-metabolizable analogues of purine nucleotides have also been reported to induce germination of $B$. cereus spores although the extent of 
germination varied with the differently modified purine nucleosides (Shibata et al., 1985).

In this study, the specific nucleoside requirements for the germination of $B$. cereus spores were investigated using a selection of adenosine analogues. The effect of varying heat-activation of spores was also studied to provide further insight into an environmental influence on the ability of the analogues to trigger germination.

\section{Methods}

Preparation of spore suspensions. Bacillus cereus NCIB 8122 was used throughout this study. Spores were produced on fortified nutrient agar (Senesi et al., 1974) supplemented with sporulation salts: $\mathrm{NaCl}$ (5.0 mg ml-1), $\mathrm{CaCl}_{2}\left(0.1 \mathrm{mg} \mathrm{ml}^{-1}\right)$, and $\mathrm{MgSO}_{4} .7 \mathrm{H}_{2} \mathrm{O}\left(2.0 \mathrm{mg} \mathrm{ml}^{-1}\right)$. Roux bottles, containing $150 \mathrm{ml}$ of the above medium, were inoculated with $3.5 \mathrm{ml}$ of spore suspension $\left(5.0 \times 10^{7}\right.$ spores $\mathrm{ml}^{-1}$ in distilled water). After incubation at $36^{\circ} \mathrm{C}$ for $72 \mathrm{~h}$, the spores were scraped from the agar with a Teflon-coated magnetic stirrer, washed five times by centrifugation ( $10000 \mathrm{~g}$ for $10 \mathrm{~min}$ ) with ice-cold distilled water and kept as a suspension containing more than $99 \%$ free refractile spores and no visible vegetative cells. The freshly harvested spores were stored at $4{ }^{\circ} \mathrm{C}$ after being diluted to about $3.0 \times 10^{9}$ spores $\mathrm{ml}^{-1}\left(\mathrm{OD}_{625} 8.0\right)$. The stock spore suspensions were used within 6-10 d for germination experiments.

Heat activation of dormant spores. Two-millilitre aliquots of the stock spore suspensions, in $5 \mathrm{ml}$ thin-walled glass tubes, were activated at 70 , 80 and $90{ }^{\circ} \mathrm{C}$ for $10,7.5$ and $3.5 \mathrm{~min}$ respectively in a water bath; heatup time was $0.25 \mathrm{~min}$. The spores were then cooled rapidly in an icewater bath, washed once as above, resuspended in ice-cold distilled water and used within $3 \mathrm{~h}$.

Spore germination. This was continuously monitored at $36^{\circ} \mathrm{C}$ by recording the decrease in $\mathrm{OD}_{625}$ of spore suspensions in a Hitachi Perkin-Elmer DB 124 spectrophotometer: $0.1 \mathrm{ml}$ of heat-activated spore suspension $\left(3.0 \times 10^{8}\right.$ spores $)$ was diluted in $0.8 \mathrm{ml} 67 \mathrm{~mm}$ potassium phosphate buffer $(\mathrm{pH} 8.2)$ and equilibrated in $1.0 \mathrm{~cm}$ lightpath semimicrocuvettes at $36^{\circ} \mathrm{C}$ for $10 \mathrm{~min}$. Germination was started by adding $0.1 \mathrm{ml}$ prewarmed $\mathrm{L}$-alanine/adenosine solution to final concentrations of $10 \mathrm{~mm}$ and $0.1 \mathrm{mM}$ respectively. Typically, the initial $\mathrm{OD}_{625}$ of 0.8 decreased within $15 \mathrm{~s}$ of the induction. The germination rate was the maximum rate of decrease of $\mathrm{OD}_{625} \mathrm{~min}^{-1}$ expressed as a percentage decrease relative to the initial $\mathrm{OD}_{625}$. The extent of germination was measured by the total decrease in $\mathrm{OD}_{625}$ expressed as a percentage of the initial value; since complete loss of spore refractility at $625 \mathrm{~nm}$ corresponded to a $60 \%$ decrease of the initial $\mathrm{OD}_{625}$, this percentage value was taken as $100 \%$ extent of germination (i.e. germinated spores) and all intermediate values were expressed according to the above proportion.

Induction of germination with adenosine analogues. When the germination-inducing activity of these analogues was assayed, the conditions were as described above, except that adenosine was replaced by the compound to be tested. Experiments were carried out at least in triplicate. The maximum rate and extent of germination were taken directly from each time-course curve. The activity of the analogues was established by determining the lowest concentration stimulating $50 \%$ spore germination within $120 \mathrm{~min}\left(\mathrm{C}_{50}\right)$. The purity of all analogues was tested by HPLC (Beckman) on C18-reversed-phase columns. Whenever contaminating nucleosides were present, only samples from the peak of authentic substance were used for germination. Samples of $8 R$-deoxycoformycin [pentostatin; $8 R$-3-(2- deoxy- $\beta$-D-erythro-pentofuranosyl)-3,6,7,8-tetrahydroimidazo(4,5$d)(1,3)$ diazepin-8-ol] and $8 S$-deoxycoformycin [8S-3-(2-deoxy- $\beta$-Derythropentofuranosyl)-3,6,7,8-tetrahydroimidazo $(4,5-d)(1,3)$ diazepin8-ol] were supplied by Dr David C. Baker (Department of Chemistry, University of Alabama, Tuscaloosa, USA). Coformycin [ $8 R-3-\beta-\mathrm{D}-$ ribofuranosyl-3,6,7,8-tetraimidazo(4,5- $d)(1,3)$ diazepin-8-ol] was obtained from Calbiochem-Behring, 2,6-diaminopurine riboside from Pfaltz \& Bauer and all other analogues from Sigma.

Determination of heat-resistance and of dipicolinic acid (DPA) during germination. Germination conditions were as described for the spectrophotometric assay, except that the final volume of germination mixtures was $20.0 \mathrm{ml}$ and phosphate buffer was replaced by $0.9 \% \mathrm{NaCl}$ plus $10 \mathrm{~mm}$-Tris/ $\mathrm{HCl}$ ( $\mathrm{pH} \mathrm{8.2)}$. Loss of heat-resistance during germination was measured at $5 \mathrm{~min}$ intervals from the onset of germination in $1.0 \mathrm{ml}$ samples which were either heated at $85^{\circ} \mathrm{C}$ for $20 \mathrm{~min}$ or unheated. Heat-resistant spores were enumerated at $30^{\circ} \mathrm{C}$ by plating, in triplicate, $0 \cdot 1 \mathrm{ml}$ samples of appropriate dilutions (Warth, 1978). Survival was expressed as a percentage of the total population. DPA release by germinating spores was measured by removing $1.0 \mathrm{ml}$ samples at $5 \mathrm{~min}$ intervals, adding $1.0 \mathrm{ml}$ cold $40 \mathrm{~mm}$-D-alanine to block any further germination (Kutima \& Foegeding, 1987) and after centrifugation determining the amount of DPA in the supernatants by either the method of Janssen et al. (1958) or that of Scott \& Ellar (1978), depending upon the amount of DPA to be measured. Purified DPA (Aldrich) was used as a standard for calibration curves. The amount of released DPA was expressed as percentage of that extracted from ungerminated spores, for which the mean value for eight separate samples was $172 \cdot 0 \pm 6 \cdot 3$ (mean $\pm \mathrm{SD}$ ) nmol per $10^{8}$ spores.

\section{Results}

\section{Heat-activation conditions and inducer concentrations to optimize spore germination}

The ability of adenosine to trigger spore germination of most $B$. cereus strains can be enhanced greatly by Lalanine as well as by prolonged heat treatment (Powell $\&$ Hunter, 1955; Warren \& Gould, 1968; Sogin et al., 1972; Yousten, 1975), but it was important to establish standard conditions in which the germination-inducing activity of the analogues could be measured.

The effects of activation at 70,80 or $90^{\circ} \mathrm{C}$ for varying times and induction by L-alanine $(10 \mathrm{mM})+$ adenosine $(0.1 \mathrm{mM})$, adenosine $(1 \mathrm{mM})$ and $\mathrm{L}$-alanine $(100 \mathrm{mM})$ were tested (Table 1). The optimum conditions for germination were activation at $70{ }^{\circ} \mathrm{C}$ for $10 \mathrm{~min}$ in $10 \mathrm{mM}$-Lalanine $+0.1 \mathrm{~mm}$-adenosine. No increase in germination rate was obtained when heat activation was extended beyond $10 \mathrm{~min}$, and the germination appeared bimodal, particularly when heating was extended beyond $30 \mathrm{~min}$, as already described by Hashimoto et al. (1972), Sogin $e t$ al. (1972) and Shacter \& Hashimoto (1975). Hence, when spores were activated at $70^{\circ} \mathrm{C}$, the germination-inducing activity of adenosine was amplified by adding L-alanine to the germination medium, since adenosine alone induced germination only when spores were activated for at least $45 \mathrm{~min}$ at that temperature (Table 1). By contrast, 
Table 1. Heat-activation conditions required for maximum germination of B. cereus NCIB 8122 spores in L-alanine + adenosine, or adenosine and L-alanine alone

Values are given as the mean \pm SD of seven separate experiments.

\begin{tabular}{|c|c|c|c|c|c|c|}
\hline \multicolumn{2}{|c|}{$\begin{array}{c}\text { Heat } \\
\text { activation }\end{array}$} & \multicolumn{2}{|c|}{$\begin{array}{l}\text { Inducer concns } \\
\qquad(\mathrm{mM})^{*}\end{array}$} & \multirow{2}{*}{$\begin{array}{l}\text { Germination } \\
\text { rate } \dagger\end{array}$} & \multirow{2}{*}{$\begin{array}{c}\text { Germination } \\
\text { extent } \dagger\end{array}$} & \multirow{2}{*}{$\begin{array}{c}t_{50 \%} \\
\text { (min) } \ddagger\end{array}$} \\
\hline$T\left({ }^{\circ} \mathrm{C}\right)$ & $t(\min )$ & L-Alanine & Adenosine & & & \\
\hline 70 & $10 \cdot 0$ & $10 \cdot 0$ & $0 \cdot 1$ & $23 \cdot 5 \pm 1 \cdot 2$ & $98 \cdot 5 \pm 0 \cdot 8$ & $2 \cdot 2 \pm 0 \cdot 1$ \\
\hline 80 & $3 \cdot 0$ & $10 \cdot 0$ & $0 \cdot 1$ & $21.9 \pm 0.8$ & $97.6 \pm 1.0$ & $2.4 \pm 0.2$ \\
\hline 90 & $1 \cdot 5$ & $10 \cdot 0$ & $0 \cdot 1$ & $20 \cdot 5 \pm 1 \cdot 3$ & $96.8 \pm 0.7$ & $2 \cdot 6 \pm 0 \cdot 1$ \\
\hline 70 & $45 \cdot 0$ & 0 & 1.0 & $6.9 \pm 0.4$ & $58 \cdot 6 \pm 1 \cdot 8$ & $24 \cdot 1 \pm 1 \cdot 4$ \\
\hline 80 & $7 \cdot 5$ & 0 & 1.0 & $13.6 \pm 0.7$ & $89.2 \pm 1.5$ & $4.6 \pm 0.6$ \\
\hline 90 & $3 \cdot 5$ & 0 & 1.0 & $14.2 \pm 0.9$ & $90.4 \pm 1.8$ & $5 \cdot 2 \pm 0 \cdot 3$ \\
\hline 70 & $25 \cdot 0$ & $100 \cdot 0$ & 0 & $2 \cdot 3 \pm 0.3$ & $45 \cdot 2 \pm 1 \cdot 2$ & ND \\
\hline 80 & $5 \cdot 0$ & $100 \cdot 0$ & 0 & $4.8 \pm 0.7$ & $70 \cdot 2 \pm 1 \cdot 6$ & $10 \cdot 8 \pm 1 \cdot 3$ \\
\hline 90 & $2 \cdot 5$ & $100 \cdot 0$ & 0 & $5.8 \pm 0.9$ & $78 \cdot 8 \pm 1 \cdot 8$ & $8.2 \pm 0.9$ \\
\hline
\end{tabular}

ND, Not detectable.

* Inducer concentrations for maximum germination rate and extent, as determined with spores activated at $70^{\circ} \mathrm{C}$.

$\dagger$ Germination rate is the maximum rate of decrease in $\mathrm{OD}_{625} \mathrm{~min}^{-1}$ and is expressed as a percentage decrease relative to the initial $\mathrm{OD}_{625}$. Extent of germination is the total decrease of $\mathrm{OD}_{625}$ expressed as a percentage of the total decrease of $\mathrm{OD}_{625}(60 \%)$ corresponding to $100 \%$ loss of spore refractility (i.e. $100 \%$ germinated spores) (see Methods).

$\ddagger$ Time required to reach $50 \%$ germination.

Table 2. Germination-inducing activity of adenosine analogues on B. cereus NCIB 8122 spores

Values are given as the mean \pm SD of seven separate experiments.

\begin{tabular}{lccc}
\hline \multicolumn{1}{c}{$\begin{array}{c}\text { Compound added } \\
(0 \cdot 1 \mathrm{mM})^{*}\end{array}$} & $\begin{array}{c}\text { Germination } \\
\text { rate } \dagger\end{array}$ & $\begin{array}{c}\text { Germination } \\
\text { extent }{ }^{\dagger}\end{array}$ & $\begin{array}{c}t_{50 \%} \\
(\mathrm{~min}){ }_{+}\end{array}$ \\
\hline None & $<0 \cdot 05$ & $7 \cdot 8$ & $\mathrm{ND}$ \\
Adenosine & $23 \cdot 5 \pm 1 \cdot 2$ & $98 \cdot 5 \pm 0 \cdot 8$ & $2 \cdot 2 \pm 0 \cdot 1$ \\
Ribose-modified analogues & $5 \cdot 4 \pm 0 \cdot 3$ & $60 \cdot 2 \pm 0 \cdot 6$ & $16 \cdot 8 \pm 0 \cdot 3$ \\
2'-Deoxyadenosine & $2 \cdot 1 \pm 0 \cdot 2$ & $14 \cdot 8 \pm 1 \cdot 7$ & $\mathrm{ND}$ \\
3'-Deoxyadenosine & $0 \cdot 9 \pm 0 \cdot 1$ & $11 \cdot 9 \pm 1 \cdot 5$ & $\mathrm{ND}$ \\
5'-Deoxyadenosine & $0 \cdot 7 \pm 0 \cdot 1$ & $25 \cdot 4 \pm 1 \cdot 6$ & $\mathrm{ND}$ \\
5'-Chloro-5'-deoxyadenosine & $0 \cdot 8 \pm 0 \cdot 2$ & $16 \cdot 8 \pm 1 \cdot 9$ & $\mathrm{ND}$ \\
5'-Amino-5'-deoxyadenosine & & & \\
Base-modified analogues & $21 \cdot 5 \pm 0 \cdot 9$ & $95 \cdot 5 \pm 0 \cdot 6$ & $2 \cdot 6 \pm 0 \cdot 1$ \\
Inosine & $24 \cdot 5 \pm 1 \cdot 1$ & $98 \cdot 5 \pm 0 \cdot 7$ & $2 \cdot 0 \pm 0 \cdot 1$ \\
6-Methoxypurine riboside & $26 \cdot 2 \pm 1 \cdot 3$ & $98 \cdot 5 \pm 0 \cdot 7$ & $1 \cdot 6 \pm 0 \cdot 6$ \\
6-Hydroxylaminopurine riboside & $14 \cdot 2 \pm 0 \cdot 7$ & $72 \cdot 8 \pm 1 \cdot 5$ & $6 \cdot 5 \pm 0 \cdot 5$ \\
Purine riboside & $7 \cdot 6 \pm 0 \cdot 5$ & $73 \cdot 1 \pm 1 \cdot 6$ & $10 \cdot 4 \pm 0 \cdot 4$ \\
1-Methyladenosine & $12 \cdot 3 \pm 0 \cdot 7$ & $94 \cdot 5 \pm 0 \cdot 8$ & $7 \cdot 8 \pm 1 \cdot 1$ \\
2,6-Diaminopurine riboside & $5 \cdot 0 \pm 0 \cdot 4$ & $58 \cdot 3 \pm 1 \cdot 8$ & $14 \cdot 4 \pm 2 \cdot 1$ \\
2-Chloroadenosine & $8 \cdot 5 \pm 0 \cdot 7$ & $85 \cdot 0 \pm 0 \cdot 9$ & $8 \cdot 2 \pm 1 \cdot 6$ \\
Formycin B & $5 \cdot 2 \pm 0 \cdot 3$ & $56 \cdot 4 \pm 1 \cdot 6$ & $15 \cdot 4 \pm 2 \cdot 1$ \\
Formycin A & & & \\
Expanded-base-ring analogues & $18 \cdot 2 \pm 1 \cdot 2$ & $95 \cdot 4 \pm 0 \cdot 6$ & $2 \cdot 8 \pm 0 \cdot 1$ \\
8R-Coformycin & $0 \cdot 1 \pm 0 \cdot 01$ & $12 \cdot 3 \pm 0 \cdot 5$ & $\mathrm{ND}$ \\
8R-2'-Deoxycoformycin & $5 \cdot 7 \pm 0 \cdot 5$ & $68 \cdot 6 \pm 1 \cdot 3$ & $16 \cdot 5 \pm 0 \cdot 5$ \\
8S-2'-Deoxycoformycin & & & \\
\hline \hline
\end{tabular}

ND, Not detectable.

${ }^{*}$ Germination was in $10 \mathrm{mM}-\mathrm{L}$-alanine plus the compound indicated, using spores heated at $70^{\circ} \mathrm{C}$ for $10 \mathrm{~min}$.

$\dagger, \downarrow$ As for Table 1. 
Table 3. Dependence of germination-inducing activity of adenosine analogues on the temperature of heat-activation of B. cereus NCIB 8122 spores

\begin{tabular}{|c|c|c|c|c|c|}
\hline \multirow[b]{2}{*}{ Compound } & \multicolumn{3}{|c|}{$\begin{array}{l}\mathrm{C}_{50}(\mu \mathrm{M})^{*} \text { with } \\
\text { L-alanine }\end{array}$} & \multicolumn{2}{|c|}{$\begin{array}{c}\mathrm{C}_{50}(\mu \mathrm{M})^{*} \text { without } \\
\text { L-alanine }\end{array}$} \\
\hline & $70^{\circ} \mathrm{C}$ & $80^{\circ} \mathrm{C}$ & $90^{\circ} \mathrm{C}$ & $80^{\circ} \mathrm{C}$ & $90^{\circ} \mathrm{C}$ \\
\hline \multicolumn{6}{|l|}{ Ribose-modified analogues } \\
\hline 2'-Deoxyadenosine & $42 \cdot 0$ & $30 \cdot 0$ & $24 \cdot 0$ & $375 \cdot 0$ & $135 \cdot 0$ \\
\hline 3'-Deoxyadenosine & $\dagger$ & $\dagger$ & $\dagger$ & $\dagger$ & $\dagger$ \\
\hline $5^{\prime}$-Deoxyadenosine & $\dagger$ & $\dagger$ & $\dagger$ & $\dagger$ & $\dagger$ \\
\hline \multicolumn{6}{|l|}{ Base-modified analogues } \\
\hline Adenosine & $17 \cdot 5$ & $12 \cdot 5$ & 8.7 & $150 \cdot 0$ & $62 \cdot 5$ \\
\hline 6-Methoxypurine riboside & $15 \cdot 0$ & $10 \cdot 0$ & $7 \cdot 5$ & $125 \cdot 0$ & $50 \cdot 0$ \\
\hline \multicolumn{6}{|l|}{ 6-Hydroxylaminopurine } \\
\hline riboside & $12 \cdot 5$ & $8 \cdot 7$ & $6 \cdot 2$ & $75 \cdot 0$ & $37 \cdot 5$ \\
\hline 1-Methyladenosine & $40 \cdot 5$ & $31 \cdot 5$ & $22 \cdot 5$ & $360 \cdot 0$ & $120 \cdot 0$ \\
\hline 2-Chloroadenosine & $45 \cdot 0$ & $36 \cdot 0$ & $27 \cdot 0$ & $405 \cdot 0$ & $225 \cdot 0$ \\
\hline Formycin A & $50 \cdot 0$ & $40 \cdot 5$ & $31 \cdot 5$ & $480 \cdot 0$ & $270 \cdot 0$ \\
\hline \multicolumn{6}{|l|}{ Expanded-base-ring analogues } \\
\hline 8 - $R$-Coformycin & $26 \cdot 0$ & $15 \cdot 0$ & $10 \cdot 0$ & $175 \cdot 0$ & $62 \cdot 5$ \\
\hline $8 R-2^{\prime}$-Deoxycoformycin & $\dagger$ & $\dagger$ & $\dagger$ & $\dagger$ & $\dagger$ \\
\hline $8 S-2^{\prime}$-Deoxycoformycin & $40 \cdot 5$ & $27 \cdot 0$ & $17 \cdot 5$ & $315 \cdot 0$ & $125 \cdot 0$ \\
\hline
\end{tabular}

* Lowest inducer concentration allowing $50 \%$ spore germination within $120 \mathrm{~min}\left(\mathrm{C}_{50}\right)$. In the presence of $10 \mathrm{~mm}$-L-alanine, $\mathrm{C}_{50}$ was determined with spores activated at $70^{\circ} \mathrm{C}$ for $10 \mathrm{~min}, 80^{\circ} \mathrm{C}$ for $3 \mathrm{~min}$ and $90{ }^{\circ} \mathrm{C}$ for $1.5 \mathrm{~min}$; in the absence of L-alanine, $\mathrm{C}_{50}$ was determined with spores activated at $80^{\circ} \mathrm{C}$ for $7.5 \mathrm{~min}$ and $90^{\circ} \mathrm{C}$ for $3.5 \mathrm{~min}$.

$\dagger$ Maximum germination was $30 \%$ at an inducer concentration as high as $5 \mathrm{~mm}$.

after heat activation at 80 or $90^{\circ} \mathrm{C}$, optimum germination was obtained with adenosine alone (although at a lower rate than in the presence of L-alanine) by heating spores for a very short time $(7.5$ and $3.5 \mathrm{~min}$ at 80 and $90{ }^{\circ} \mathrm{C}$, respectively). Such heating did not appear to stimulate bimodal germination even in presence of $\mathrm{L}$ alanine. It was therefore possible: (i) to analyse the germination-inducing activity of adenosine analogues with respect to adenosine alone and (ii) to compare the enhancing effect of L-alanine or of heating on the activity of the analogues as inducers of spore germination.

Effects of sugar-or base-modified adenosine analogues on spore germination

Most of the experiments to screen adenosine analogues for their ability to induce spore germination were done in $10 \mathrm{~mm}$-L-alanine with spores activated at $70^{\circ} \mathrm{C}$ for $10 \mathrm{~min}$ (Table 2). The nucleosides modified in their sugar moiety were generally strongly impaired as germinants. Although the ribose-modified analogues tested were very closely related compounds, only 2'deoxyadenosine actively triggered germination, but to a lesser extent than adenosine (Table 2). This suggests that the germination-inducing activity of purine nucleosides is strictly regulated by the properties of the ribosyl moiety, the unmodified structure of which is essential for the initiation of B. cereus spore germination. By contrast, none of the base-modified analogues was totally inactive as a germinant. In fact, those with modifications at C-6 were even better inducers of germination than adenosine. Only 2-chloroadenosine and formycin A resulted in sluggish germination, but they stimulated $50-60 \%$ germination. Collectively, these results show that the structural properties of the base moiety of purine nucleosides do not greatly affect germination induction, although there are minor differences in both the rate and the extent of germination.

In order better to quantify the germination-inducing activity of the different analogues, the lowest concentration resulting in $50 \%$ spore germination in $120 \mathrm{~min}\left(\mathrm{C}_{50}\right)$ was measured. To determine the heat-activation dependence of their germination-inducing activity, spores were activated at 70,80 or $90^{\circ} \mathrm{C}$ and germinated in L-alanine (Table 3 ). To rule out the possibility that L-alanine might affect the activity of the different analogues, experiments were also performed in the absence of L-alanine using spores activated at $80^{\circ} \mathrm{C}$ for $7.5 \mathrm{~min}$ or at $90{ }^{\circ} \mathrm{C}$ for $3.5 \mathrm{~min}$. Germination of $50 \%$ of the spores was achieved at different concentrations of the inducer, depending upon the activation temperature; in general, the higher the activation temperature the lower the $\mathrm{C}_{50}$ of the inducer, in both the presence and absence of L-alanine. Nevertheless, the differences in 


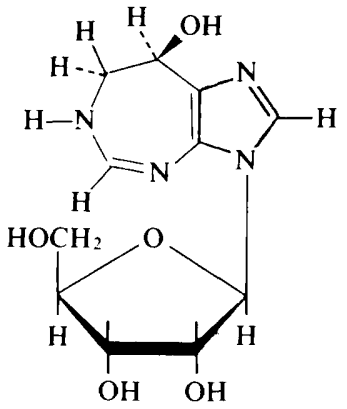

$8 R$-Coformycin

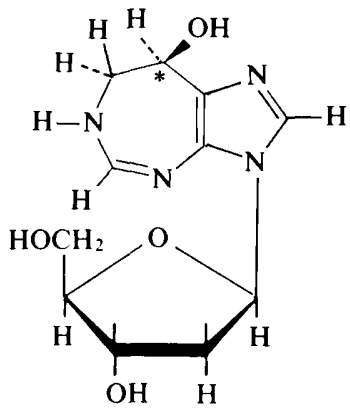

$8 R-2^{\prime}$-Deoxycoformycin (Pentostatin)

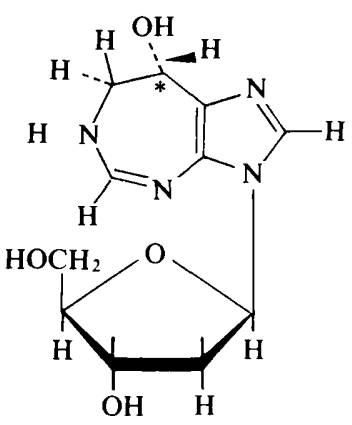

$8 S-2$-deoxycoformycin

Fig. 1. Molecular structure of expanded base ring analogues of adenosine. Position 8 is marked with a star.

Table 4. DPA release and loss of heat-resistance by B. cereus NCIB 8122 spores during germination in either $8 R-2^{\prime}$-deoxycoformycin or $8 S-2^{\prime}$-deoxycoformycin

Spores were activated at $70{ }^{\circ} \mathrm{C}$ for $10 \mathrm{~min}$. The germination medium $(0.9 \% \mathrm{NaCl}+10 \mathrm{~mm} \mathrm{Tris} / \mathrm{HCl}$, $\mathrm{pH} 8 \cdot 2$ ) contained $3.0 \times 10^{8}$ spores $\mathrm{ml}^{-1}$ and $10 \cdot 0 \mathrm{~mm}$-L-alanine.

\begin{tabular}{|c|c|c|c|c|}
\hline \multirow{3}{*}{$\begin{array}{l}\text { Sampling } \\
\text { time } \\
\text { (min) }\end{array}$} & \multicolumn{4}{|c|}{ Germination in the presence of } \\
\hline & \multicolumn{2}{|c|}{$0 \cdot 1 \mathrm{~mm}-8 R-2^{\prime}$-deoxycoformycin } & \multicolumn{2}{|c|}{$0 \cdot 1 \mathrm{~mm}-8 S-2^{\prime}$-deoxycoformycin } \\
\hline & DPA release* & $\begin{array}{c}\text { Loss of } \\
\text { heat-resistance } \dagger\end{array}$ & DPA release* & $\begin{array}{l}\text { Loss of } \\
\text { heat-resistance } \dagger\end{array}$ \\
\hline 5 & $0 \cdot 1$ & 0.9 & $10 \cdot 0$ & $15 \cdot 0$ \\
\hline 10 & $2 \cdot 3$ & $5 \cdot 8$ & $25 \cdot 0$ & $36 \cdot 0$ \\
\hline 15 & $4 \cdot 2$ & 13.7 & $47 \cdot 0$ & $52 \cdot 0$ \\
\hline 30 & 6.7 & $28 \cdot 6$ & $56 \cdot 0$ & $79 \cdot 0$ \\
\hline
\end{tabular}

* DPA release is expressed as a percentage of the total DPA content of ungerminated spores in the spore suspension $(516 \cdot 0 \pm 12.6 \mathrm{nmol})$.

$\dagger$ Expressed as the percentage of the total population sensitive to heating at $85^{\circ} \mathrm{C}$ for $20 \mathrm{~min}$.

ability to trigger germination, based on comparisons of the maximum germination rate at a given analogue concentration (Table 2), did not appear to be modified significantly when expressed as $\mathrm{C}_{50}$. As expected, such values were lower for each analogue in the presence of L-alanine.

\section{Effects of adenosine analogues with an expanded base} ring on spore germination

As can be seen in Fig. 1, 2'-deoxycoformycin diastereoisomers and coformycin have a partly saturated expanded base dihydrohomopurine ring characterized by the presence of an asymmetric carbon atom at position 8 . In addition, the 2'-deoxycoformycins also lack the hydroxyl group at position 2 of the ribose moiety. Coformycin was nearly as active as adenosine in triggering spore germination, with or without L-alanine and at any activation temperature tested (Tables 2 and 3). These results further support the conclusion that the germination-inducing activity of purine nucleosides depends only slightly, if at all, on the structural properties of the base ring, since the dihydrohomopurine nucleosides are effective in rapidly triggering germination.

When 2'-deoxycoformycins were used as germinants, $8 S$-2'-deoxycoformycin was as active as $2^{\prime}$-deoxyadenosine, the most active ribose-modified nucleoside tested, but the $8 R$-diastereoisomer was almost devoid of germination-inducing activity (Table 2). Similar results were obtained when germination was monitored by different procedures (Table 4). The stringent requirement for the stereospecific configuration of nucleosides acting as germinants cannot be compared with that of $D$ alanine (vs L-alanine) in the same process. Indeed, while D-alanine strongly inhibits L-alanine-triggered germination (Hills, 1949b), no inhibitory effect was observed on the germination rate even when the $R$-isomer was tested at a concentration twice that of the $S$-diastereoisomer. 


\section{Conclusions}

Two major conclusions can be drawn from these results, as follows.

(i) If signal transduction results from the interactions of the analogues with a putative receptor, the varying affinity for purine nucleosides could relate to their different germination-inducing activities. However, the relationship between the structural feature and the activity of the various analogues has not been clearly established, except that the ability to promote germination appears most likely to be related to the structural properties of the sugar rather than the base moiety of the nucleosides. The requirement for an unmodified ribosyl structure to trigger germination rapidly has already been suggested (Shibata et al., 1985), but their germination experiments were carried out with distantly related compounds and the spores were subjected to prolonged heat treatment $\left(70{ }^{\circ} \mathrm{C}\right.$ for $30 \mathrm{~min}$ and in the presence of $\mathrm{L}$ alanine), conditions resulting in much interference with B. cereus spore germination (Sogin et al., 1972; Shacter \& Hashimoto, 1975).

(ii) The stereospecific configuration of the inducer appears to be critical for the rapid induction of the germination of $B$. cereus spores, at least in the case of 2'deoxycoformycin. Whatever the nature of the spore structure interacting with nucleosides, it must also discriminate between opposite configurations at the C-8 of 2'-deoxycoformycin. As confirmation, it would be interesting to assay the germination-inducing activity of $8 S$-coformycin, since the natural compound has the $R$ configuration at position 8 . Unfortunately, its $8 S$ diastereoisomer is not yet available, so one can only speculate that, if the $S$ configuration at position 8 contributes to the enhancement of the germination induction by the 2 -deoxyribonucleosides, it could also influence the inducing activity of the ribonucleosides.

This work was supported by grants from the 'Ministero dell'Università e della Ricerca Scientifica e Tecnologica', Rome. We are very grateful to Dr David C. Baker for his generous gift of the 2'deoxycoformycin diastereoisomers.

\section{References}

Foster, S. J. \& Johnstone, K. (1990). Pulling the trigger: the mechanism of bacterial spore germination. Molecular Microbiology 4. $137-141$.

Hashimoto, T., Frieben, W. R. \& Conti, S. F. (1972). Kinetics of germination of heat-injured Bacillus cereus spores. In Spores $V$, pp. 409-415. Edited by H. O. Halvorson, R. Hanson \& L. L. Campbell. Washington, DC: American Society for Microbiology.

Hills, G. M. (1949a). Chemical factors in the germination of sporebearing aerobes. The effect of amino acids on the germination of Bacillus anthracis and its replacement by adenosine. Biochemical Journal 45, 353-362.
Hills, G. M. (1949b). Chemical factors in the germination of sporebearing aerobes. The effect of amino acids on the germination of Bacillus anthracis with some observations on the relation of optical form to biological activity. Biochemical Journal 45, 363-370.

JANSSEN, F. W., Lund, A. J. \& ANDERSON, L. E. (1958). Colorimetric assay of dipicolinic acid in bacterial spores. Science 127, 26-27.

Keynan, A. (1978). Spore structure and its relations to resistance, dormancy, and germination. In Spores VII, pp. 43-53. Edited by G. Chambliss \& J. C. Vary. Washington, DC: American Society for Microbiology.

KeYNAN, A. \& SANDLER, N. (1983). Spore research in historical perspective. In The Bacterial Spore, vol. 2, pp. 1-48. Edited by A. Hurst \& G. W. Gould. London: Academic Press.

Kutima, P. M. \& Foegeding, P. M. (1987). Involvement of the spore coat in germination of Bacillus cereus $\mathrm{T}$ spores. Applied and Environmental Microbiology 53, 47-52.

LAWRENCE, L. N. (1955a). The cleavage of adenosine by spores of Bacillus cereus. Journal of Bacteriology 70, 577-582.

LAWRENCE, L. N. (1955 b). The relationship between the cleavage of purine ribosides by bacterial spores and germination of the spores. Journal of Bacteriology 70, 583-587.

Powell, J. F. \& Hunter, J. R. (1955). Spore germination in the genus Bacillus : the modification of germination requirements as a result of preheating. Journal of General Microbiology 13, 59-67.

Powell, J. F. \& Hunter, J. R. (1956). Adenosine deaminase and ribosidase in spores of Bacillus cereus. Biochemical Journal 62, 381387.

ScotT, I. R. \& Ellar, D. J. (1978). Study of calcium dipicolinate release during bacterial spore germination by using a new sensitive assay for dipicolinate. Journal of Bacteriology 135, 133-137.

Senesi, S., Falcone, G., Ipata, P. L. \& Felicioli, R. A. (1974). Inhibition of phosphodiesterases from Bacillus subtilis by nucleoside triphosphates. Biochemistry 13, 5008-5011.

Senesi, S., Falcone, G., Mura, U., Sgarrella, F. \& Ipata, P. L. (1977). Adenosine phosphorylase from vegetative forms and free spores of Bacillus subtilis: properties and possible physiological role. In Spore Research 1976, vol. I, pp. 311-333. Edited by A. N. Barker, L. J. Wolf, D. J. Ellar, G. J. Dring \& G. W. Gould. London: Academic Press.

SETlow, P. (1983). Germination and outgrowth. In The Bacterial Spore, vol. 2, pp. 211-254. Edited by A. Hurst \& G. W. Gould. London: Academic Press.

Shacter, S. M. \& Hashimoto, T. (1975). Bimodal kinetics of germination of Bacillus cereus T spores. In Spores VI, pp. 531-538. Edited by P. Gerhardt, R. N. Costilow \& H. L. Sadoff. Washington, DC: American Society for Microbiology.

Shibata, H., Ohnishi, N., Takeda, K., Fukunaga,. H., Shimamura, K., Yasunobu, E. \& TANI, I. (1985). Germination of Bacillus cereus spores induced by purine ribosides and their analogs: effects of modification of base and sugar moieties of purine nucleosides on germination-inducing activity. Canadian Journal of Microbiology 32. $186-189$.

Sogin, M. L., MaCCall, W. A. \& Ordal, Z. J. (1972). Effect of heat activation conditions on the germinal response of Bacillus cereus $\mathrm{T}$ spores. In Spores V, pp. 363-367. Edited by H. O. Halvorson, R. Hanson \& L. L. Campbell. Washington DC: American Society for Microbiology.

Warren, S. C. \& Gould, G. W. (1968). Bacillus cereus spore germination: absolute requirement for amino acid. Biochimica et Biophysica Acta 170, 341-350.

WARTH, A. D. (1978). Relationship between the heat resistance of spores and the optimum growth temperatures of Bacillus species. Journal of Bacteriology 134, 699-705.

Weinberger, S., Evenchik, Z. \& Hertman, I. (1980). Utilization of purine nucleosides by germinating Bacillus cereus 569 spores. Journal of General Microbiology 118, 223-228.

Yousten, A. A. (1975). Germination of Bacillus cereus endospores: a proposed role for heat shock and nucleosides. Canadian Journal of Microbiology 21, 1192-1197. 